\title{
The Use of Biobased Active Packaging Components in Biopolymers
}

\author{
Mehmet Seckin Aday (Corresponding author) \\ Engineering Faculty, Food Engineering Department, \\ Canakkale Onsekiz Mart University, Canakkale, Turkey \\ E-mail: mseckinaday@comu.edu.tr
}

\begin{abstract}
Although petroleum-based packaging materials are widely used in food technology, the alternative materials can be considered due to the environmental concerns and changes in petroleum prices. Biobased polymers, which seems as one of these solutions, could not reach the desired level because of their low mechanical and barrier properties. Therefore, biobased active components can be added to these polymers to ensure the desired properties of films. In addition, these active components can extend the shelf life of the packaged foods. In this review, the use of biobased active components in biobased polymers are summarized.
\end{abstract}

Keywords: Biobased active components, Biobased polymers, Food technology

DOI: $10.7176 / J S T R / 7-01-04$

\section{Biyobazlı Aktif Ambalajlama Bileşenlerinin Biyopolimerlerde Kullanımı}

\begin{abstract}
Özet
Petrol bazlı ambalaj malzemeleri, gıda sektöründe oldukça yaygın olarak kullanılsa da çevresel kaygılar ve petrol fiyatlarındaki değişimler nedeniyle bunların yerine kullanılabilecek alternatif malzemeler düşünülmektedir. Bu çözüm yollarından bir tanesi olarak göze çarpan biyobazlı polimerler ise, düşük mekanik ve bariyer özellikleri nedeniyle istenilen seviyeye gelememiştir. $\mathrm{Bu}$ nedenle, bu polimerlere eklenecek olan biyobazlı aktif bileşenlerle istenilen özellikler sağlanabilecektir. Ayrıca, bu aktif bileşenler ambalajlanan gıdaların raf ömürlerini artırabilecektir. Bu derlemede, biyobazlı aktif bileşenlerin biyobazlı polimerlerde kullanımı özetlenmektedir.
\end{abstract}

Anahtar Kelimeler: Biyobazlı aktif bileşenler, Biyobazlı polimerler, Gıda teknolojisi

\section{Giriş}

Son yıllarda gıda ile temasta olan ambalaj materyalleri için gereksinimler sistematik olarak büyümektedir. Çünkü tüketiciler, daha taze ve daha uzun raf ömrüne sahip gıdaları tercih etmektedir. Üreticiler de bu nedenle tüketicilere daha modern ve daha güvenli ambalajlar sunmak zorunda kalmışlardır (Barska ve WyrWa, 2017).

Geleneksel gıda ambalajlama sistemleri; koruma, iletişim, rahatlık ve ürünü içerme amaçlıdır. Ambalaj; gıdayı 1Sı, ışık, nem, basınç, mikroorganizmalar ve gaz bileşimi gibi dış çevre koşullarının bozucu etkilerinden korumak için kullanılır. Ayrıca tüketiciye daha fazla kullanım kolaylı̆̆ı ve zaman tasarrufu sağlar. Bunun yanında çeşitli boyut ve şekillerde ürün içerir. Gıdayla temas halinde olan geleneksel ambalaj malzemeleri için temel hedef, mümkün olduğunca inert olmaktır (Biji ve ark., 2015). Bu kriterleri karşılayan ambalajlar, gıda endüstrisi tarafından elli yılı aşkın süredir kullanılan kopolimer bazlı malzemelerdir. Bu malzemeler sadece güvenli, ucuz, çok yönlü değil aynı zamanda esnektir. Sayılan avantajlar dışında, plastik ambalajlarda yaşanan en önemli problem ise geri dönüşüm

40 | P a g e

www.iiste.org 
zorluklarıdır. Ayrıca tüketiciler son yıllarda gıda ambalaj malzemelerinin daha doğal, tek kullanımlık ve biyolojik olarak parçalanabilir olmasını talep etmektedir. $\mathrm{Bu}$ özelliklere sahip ambalajlama malzemeleri, tarımsal veya deniz kaynaklı olarak elde edilen biyobazlı ambalaj materyallerini içermektedir (Cutter, 2006).

Geleneksel ambalajlardan farklı olarak işlev gören modern gıda ambalajları ise; gıdanın korunmasında (işleme ve depolama sırasında) dinamik bir rol oynayarak ürünün güvenliğini ve kalitesini koruyan aktif bir işlevle karakterize edilmektedir. Diğer bir deyişle, gıdayla temas eden geleneksel ambalaj malzemelerinde inertlik esasken; yenilikçi ambalajlama sistemlerinde ise, gıdaya aktif koruma sağlamak için ambalaj ve gıda arasındaki yararlı etkileşimin oluşturulması amaçlanmaktadır (Drago ve ark., 2020). Yenilikçi ambalajlama teknolojileri içerisinde; mikroperfore, biyobozur, aktif ve akıllı olmak üzere literatürde çeşitli teknolojiler yer almaktadır. Bu tekniklerden aktif ve akıllı ambalajlama teknolojileri bazı durumlarda birbirinin yerine kullanıldığından, ikisinin tanımının netleştirilmesi gerekmektedir. Buna göre aktif ambalajlama, gıda ve ambalaj arasında istenen etkileşimi meydana getirmek için çeşitli aktif bileşenlerin sisteme eklenmesiyle gıdanın raf ömrünü artırmayı amaçlamaktadır. Akıllı ambalajlamada ise çeşitli iç ve dış göstergeler kullanılarak, gıdaların taşınması veya depolanmasında meydana gelen değişimler hakkında bilgi sağlanmaktadır (Aday ve Yener, 2014). Tüketiciler son yıllarda gıda ambalajlamada iki başlığa önem vermektedir. Bunlardan ilki çevresel olarak sürdürülebilir ambalajla ilgili olup, çoğunlukla biyoplastik olarak adlandırılırlar ve petrol türevli polimerlerin kısmi ikameleri olarak kullanılır. Diğer başlık ise, ürünün pasif muhafazası ve korunması dışında aktif işlevler içeren aktif ambalajlama sistemleriyle ilgilidir (Ortenzi ve ark., 2020). Bu nedenle hem biyoaktif ambalajlama fonksiyonuna sahip hem de biyobozunur özellikte olan ambalajlar göze çarpmaktadır. Çünkü, bu tip ambalajların kullanılmasıyla hem gıdaların raf ömrü uzatılabilecek hem de çevresel kaygılar ortadan kaldırılabilecektir. Fakat literatürde, genellikle biyobazlı aktif bileşenlerin sentetik polimerlere eklendiği veya biyopolimerlerde sentetik aktif bileşenlerin kullanılmasına yönelik çalışmalar bulunmaktadır. Hem biyopolimerlerin hem de biyobazlı aktif bileşenlerin aynı anda kullanıldığı çalışmalar ise oldukça kısıtlıdır. Bu nedenle bu derlemenin amacı; biyobazlı polimerlerle, biyobazlı aktif bileşenler hakkında bilgi vermektir.

\section{Biyobazlı Polimerler}

Son yıllarda, ambalaj ve gıda endüstrilerinin ortak çabaları sonucunda, kullanılan gıda ambalaj malzemesi miktarı azaltılmaya çalışılmaktadır. Buna rağmen, kullanılan ambalaj malzemeleri, bertaraf bağlamında tüketicilerin göz önünde hala bir sorun olarak durmaktadır (Petersen ve ark., 1999). Çünkü, çöp sahalarında bu tür ambalaj malzemelerinin varlığı birçok açıdan sorun yaratmaktadır. Birinci sorun, geri dönüşümün sağlanamaması durumunda, bu öğelerin çok uzun süre bozulmayacakları, çöplüklerde biriktirilmesidir. İkinci sorun; birçok ülkenin, özellikle yoğun nüfuslu alanlarda, çöp sahalarında bir azalma ile karşı karşıya olmasıdır. Üçüncü sorun ise, mevcut çöp sahalarının devlet otoriteleri tarafından belirlenen yeni düzenleyici yönergeleri karşılayamaması sonucunda kapanma ihtimalidir (Cutter, 2006).

Sayılan nedenler, tüketiciler için giderek daha önemli hale geldiğinden dolayı, yenilenemeyen kaynaklardan üretilen malzemelere alternatif olarak biyobazlı ambalaj malzemelerinin kullanımı tetiklenmektedir. Tanım olarak; biyobazlı gida ambalaj malzemeleri, yenilenebilir kaynaklardan elde edilen malzemeler olup, bu malzemelerin gidaya uygulamalarını kapsamaktadır. Bununla birlikte, biyobazlı ve biyobozunur terimleri de aynı anlama gelmemektedir. Çünkü, biyobazlı malzemeler biyolojik olarak parçalanabilirliliğe sahipken, biyobobozunur malzemelerin ise biyobazlı olmasına gerek yoktur. Son gelişmeler biyobozunur malzemelerin, polyester kaynaklı olabileceğini de göstermektedir (Weber ve ark., 2002). Biyobozunur malzemeler terimi ise bakteriler, mayalar ve mantarlar gibi canlı organizmaların enzimatik etkisiyle parçalanabilen malzemeleri ve bozunma sürecinin nihai son ürünlerini tanımlamakta olup, bunlar aerobik koşullar altında; $\mathrm{CO}_{2}$ ve $\mathrm{H}_{2} \mathrm{O}$ 'dur. Anaerobik koşullar altında ise hidrokarbonlar ve metandır (Avella ve ark., 2005). Biyobozunur polimerlerden bazıları aşağıda özetlenmiştir.

\subsection{Nişasta}

Nişasta, doğada yaygın olarak bulunabilen ve biyolojik olarak kolay parçalanabilen doğal bir kaynaktır (Peelman ve ark., 2013). Bitkilerde karbonhidrat rezervi görevi görmekte olup, pirinç dışında mısır, buğday, patates, arpa, sebze, tatlı patates, soya, yulaf vb. ürünlerden de nişasta elde edilmektedir. Nişastanın amiloz ve amilopektin olmak üzere iki bileşeni bulunmaktadır. Amiloz yapının \% 20-30'unu oluşturmakta ve $\alpha-1,4$ glikozidik bağ ile birbirine bağlanmış $\alpha$-D-glikoz birimlerinden meydana

41 I $P$ a g e

www.iiste.org 
gelmektedir. Oldukça dallanmış polimer olan amilopektinde (yapının -\%70'i), ise $\alpha-1,4$ bağlantılı zincirler, düzenli aralıklarla $\alpha-1,6$ bağlantılarıyla dallanmaktadır. Yüksek amiloz içeren nişasta daha iyi akış özelliklerine sahip olduğundan, termoplastik nişastanın hazırlanmasında tercih edilmektedir (Niranjana Prabhu ve Prashantha, 2018).

Nişasta bazlı filmler; hem 1 sıl işlem hem de dökme teknikleriyle elde edilebilmektedir. Bununla birlikte, bu filmler yalnızca nişastanın jelatinizasyonundan sonra üretilebilmektedir. Jelatinizasyon; dökme film üretim tekniğinde $>\% 90$ a/a su varlığında meydana gelebildiği gibi, ısıl işlem tekniğinde ise yüksek basınç koşullarını gerektirmektedir. $\mathrm{Bu}$ işlem sırasında; su veya gliserol gibi plastikleştiricilerin varlığı; nişasta granüllerini parçalamakta ve suyun daha hızlı transfer olmasını sağlayarak, amilopektin matriksinin kırılmasına ve amilozun serbest bırakılmasına neden olmaktadır (Muller ve ark., 2017). Gıda ambalajlama alanında, nişasta bazlı malzemeler biyolojik olarak parçalanabilirliği ve geniş bulunabilirliği yanında, düşük maliyeti (kg başına 1 euro'dan az) nedeniyle de büyük ilgi görmektedir (Avella ve ark., 2005). Ayrıca şeffaflık ve koku açısından geleneksel ambalaj plastiklerine benzer fiziksel özellikler sergilemektedir (Muller ve ark., 2017). Fakat nişastanın yüksek hidrofilik yapısı nedeniyle, nişastadan üretilen ambalaj filmleri zayıf bariyer (gaz ve neme karşı) ve düşük mekanik özelliklere sahip olmaktadır (Avella ve ark., 2005; Bhat ve ark., 2013). Nişastadaki moleküller arası kuvvetlerin yüksek olması, üretilen filmlerin çok kırılgan olmasını sağladığından; uygun polimer tabakaları elde etmek için plastikleştirici eklemek gerekmektedir. Plastikleştiricilerin kullanımı; esnekliği artırırken, su buharı ve gazlara karşı geçirgenliğini de artırmakta, bu da biyopolimerlerin gıda ambalajı için kullanılmasını sınırlamaktadır. Esnekliğin artmasının nedeni bu amaçla kullanılan gliseroldeki hidroksil grupların neden olduğu molekül içi ve moleküller arası etkileşimlerdir (Heydari ve ark., 2013). Nişasta filmlerinin mekanik ve bariyer özellikleri; polimer matrikse çapraz bağlayıcılar (Kaewtatip ve Thongmee, 2013), hidrofobik bileşenler veya nanopartiküller eklenmesiyle geliştirilebilmektedir (Chung ve ark., 2010; Noorbakhsh-Soltani ve ark., 2018). Nişasta bazlı filmlere polifenol bakımından zengin olan kırmızı lahana, kekik ve yerba mate gibi ürünlerden elde edilen özlerin eklendiği çalışmalar aktif ambalajlama konseptinde değerlendirilebilmektedir (Piñeros-Hernandez ve ark., 2017).

\subsection{Selüloz}

Selüloz yenilenebilir, biyolojik olarak parçalanabilir ve toksik olmayan bir malzemedir. Aynı zamanda çevre dostu ve biyouyumlu ürünler için geniş bir kaynaktır. Fotosentez yoluyla selüloz üretiminin $10^{11}$ $10^{12} \mathrm{t} / \mathrm{y} 1 \mathrm{l}$ olduğu tahmin edilmektedir. Selülozun başlıca kaynakları odun ve pamuktur (Nechyporchuk ve ark., 2016). Bir biyopolimer olan selüloz, tüm bitki liflerinin ana bileşenidir ve selüloz, $\beta-1-4-$ bağlantılarıyla birbirine bağlanmış $\beta$-d-glukopiranoz birimlerinden oluşan doğrusal bir homopolisakkaritten oluşmaktadır. Yinelenen birim, selübiyoz olarak bilinen bir glikoz dimeridir. Biyolojik bozunurluk ve yenilenebilirliğin yanı sıra, selülozik liflerin nano boyutlarda üretilmesi, yüksek mekanik özellikler gibi umut verici özellikleri de barındırmaktadır (Abdul Khalil ve ark., 2014). Selüloz, sodyum hidroksit ve karbon disülfit karışımı içeren çözeltide çözülerek selüloz ksantat haline gelmekte ve daha sonra hidroklorik asit solüsyonuna daldırılarak selofan filme dönüşmektedir (Jabeen ve ark., 2015). Selofan filmlerin yüzeylerinin iki yağ asidiyle esterifiye edilmesiyle su buharı ve gaz geçirgenliğinde azalma görülmektedir. Selofan filmler dışında, selüloz asetat da gıda ambalajlamada kullanılmaktadır. Selüloz asetat filmlere L-lizozim ve L-tirozin gibi antioksidantlar eklenerek aktif ambalajlama konsepti yaratılabilmektedir. Ayrıca, potasyum sorbat veya sodyum propiyonat eklenerek, selüloz asetat filmlere antimikrobiyal özellikte kazandırılabilmektedir. Metilselüloz da yenilebilir film olarak kullanılan diğer bir selüloz bazlı biyopolimerdir (Paunonen, 2013). Selüloz türevlerini elde etmenin bir başka yolu ise, selülozun hidroksil gruplarının esterifikasyonu veya eterleştirilmesi işlemidir. Bu selüloz esterlere, selüloz (di) asetat ve selüloz (tri) asetat gibi katkı maddeleri eklenerek termoplastik malzemeye dönüştürülmektedir. Son olarak da laminasyon, injeksiyon veya ekstrüzyonla işlenerek, iyi film oluşturma özellikleri sergilemesi sağlanmaktadır (Jabeen ve ark., 2015). Bu tekniklerin dışında selülozun Achromobacter, Alcaligenes, Aerobacter, Agrobacterium, Azotobacter, Komagataeibacter, Pseudomonas, Rhizobium, Sarcina, Dickeya ve Rhodobacter gibi çeşitli aerobik bakteriler vasitasıyla sentezlenmesi de mümkündür. Bitki selülozunun aksine, bakteriyel selüloz saf bir şekilde sentezlenmekte ve lignin, hemiselüloz veya pektin gibi diğer bitkisel molekül kalıntıları içermemektedir. Bu nedenle bakteriyel selülozun saflığı bitkisel selüloza göre bir avantaj olup, pahalı ekstraksiyon ve saflaştırma süreçleri ve çevreye zararlı kimyasalların kullanımını gerektirmemektedir (Cazón ve Vázquez, 2021).

42 | $\mathrm{P}$ a g e

www.iiste.org 


\section{$2.3 \mathrm{Kitin} /$ Kitosan}

Kitin ve kitosan üretimi, yengeç ve karides kabuklarına dayanmaktadır. Kitin, diğer bileşenlerle sıkı bir şekilde bağlantılı olduğundan, bunları ekstrakte edebilmek için yoğun asidik/alkali işlemler gerekmektedir. Kitosan elde etmek için, kitin yüksek sıcaklıkta güçlü $\mathrm{NaOH}$ ile $\mathrm{N}$-asetil gruplarını deesterifiye etme amaçlı işlenmekte, yıkanmakta ve kurutulmaktadır (Srinivasa ve Tharanathan, 2007). Kitosanın özelliklerini; alkali konsantrasyonu, inkübasyon süresi, kitinin alkaliye oranı, sıcaklık, atmosfer, kitin kaynağı türü, partikül boyutu, heterojen/homojen N-deasetilasyon gibi farklı faktörler etkilemektedir. Ayrıca kitosan içeriğindeki katyonik grupların, bakteri, maya ve küflere karşı antimikrobiyal etki gösterdiği saptanmıştır (van den Broek ve ark., 2015). Antimikrobiyal etki mekanizmasının ilki; bakterilerin hücre yüzeyindeki negatif yüklerle, kitosandaki pozitif yüklerin etkileşimi sonucudur. İkinci mekanizma ise; düşük molekül ağırlığında olan kitosanın hücrelerin çekirdeğine girerek, DNA moleküllerine nüfus etmesi ve bunun sonucunda da RNA transkripsiyonunu engellemesine bağlıdır (Goy ve ark., 2009). Kitosan antimikrobiyal özelliklerinin yanında; anti-kanser, antioksidan ve antikoagülan özellikler gösteren yenilenebilir, biyolojik olarak uyumlu, biyolojik olarak parçalanabilir ve toksik olmayan özellikleriyle de göze çarpmaktadır (Hamed ve ark., 2016).

Kitosan, seyreltik asit çözeltilerinde (örneğin, asetik asit ve hidroklorik asit) çözülebilmekte ve yenilebilir filmlere dönüştürülebilmektedir. Kitosan filmlerin; mukavemetini, uzatılabilirliğini, esnekliğini ve zincir hareketliliğini geliştirmek için gliserol ve sorbitol gibi az miktarda plastikleştirici ortama eklenebilmektedir. Ayrica Tween-80, Tween 20, Brij 56 ve Span 20 gibi emülgatörler veya yüzey aktif maddeler de oluşturulan filmlerin özelliklerinin iyileştirilmesinde kitosan çözeltisine katılmaktadır (Wang ve ark., 2018). Kitosan filmlerin mekaniksel özellikleri iyi olup, gazlara karşı $\left(\mathrm{CO}_{2}\right.$ ve $\left.\mathrm{O}_{2}\right)$ seçici bir geçirgenlik göstermektedir. Bununla birlikte, hidrofilik olması nedeniyle, neme karşı zayıf bir bariyere sahiptir (Miteluț ve ark., 2015). Kitosanın su buharı geçirgenlik değeri; molekül ağırlı̆̆1, deasetilasyon derecesi ve kitosan içeriği gibi özelliklerine bağlı olmakla birlikte, ölçüm yöntemi, ölçüm koşulları (bağıl nem ve sıcaklık), saklama süresi ve koşulları gibi çeşitli dış faktörlerden de etkilenmektedir (Cazon ve Vazquez, 2020). Kitosan filmler tek başına oluşturulabildiği gibi, polisakkarit ve protein gibi diğer biyopolimerlerle blend olarak da üretilebilmektedir. Bu amaçla kitosanın; nişasta, selüloz, aljinat, pektin, kazeinat, lizozim ve jelatin gibi bileşenlerle birlikte kullanıldığ

\subsection{Polilaktik Asit}

Polilaktik asit, fermentasyonla üretilen yenilenebilir bir hammadde olan laktik asidin klasik polimerizasyonu yoluyla elde edilmektedir. Üretim süreçlerinde Lactobacillus delbrueckii, L. bulgaricus, L. leichmanii olarak bilinen homolaktik organizmalar kullanılmaktadır. Karbonhidrat kaynağı olarak ise; melas, mısır şurubu, peynir altı suyu, dekstroz, şeker kamışı veya şeker pancarından yararlanılmaktadır (Datta ve ark., 1995). Laktik asidin kimyasal yapısında yer alan asimetrik karbon atomu, L- ve D-izomerleri olarak bilinen iki optik aktif konfigürasyon içermektedir. L-/D-monomer birimlerinin oranı; makromoleküllerin kristallik derecesi, erime sıcaklığı ve işleme kolaylığı gibi bazı önemli özelliklerini etkilemektedir (Tawakkal ve ark., 2014).

Polihidroksialkanoatlar (PHA) ve polietilen glikol (PEG) gibi biyopolimerlerle karşılaştırıldığında, PLA'nın termal işlenebilirliğinin iyi olması; ekstrüzyon ve dökme film gibi çeşitli işleme yöntemleriyle üretilebileceği anlamına gelmektedir. PLA'nın farklı moleküler ağırlıklarda türleri olmakla birlikte, ambalaj endüstrisinde yüksek moleküler ağırlıklı PLA'lar kullanılmaktadır (Gan ve Chow, 2018). Polilaktatlar, yaklaşık $55^{\circ} \mathrm{C}$ 'lik bir camsı geçiş sıcaklığına ve $170^{\circ} \mathrm{C}^{\prime}$ ye kadar bir erime noktasına sahiptir. Kontrollü koşullar altında biyolojik olarak parçalanabilmekte ve standart makineler kullanılarak işlenebilmektedir (Bastioli, 2001). Ayrıca, PLA’nın gıda ile temas halinde kullanımı ABD Gıda ve İlaç Dairesi tarafından da onaylanmıştır (Siracusa ve ark., 2012). Bununla birlikte PLA üretimi, aşağıdakiler dahil olmak üzere birçok avantaja sahiptir: (a) yenilenebilir bir tarımsal kaynak olan mısırın fermantasyonu ile üretilen laktik asitten laktit monomerinin üretimi; (b) önemli enerji tasarrufu; (c) hidroliz veya alkoliz ile laktik aside geri dönebilme yeteneği; (d) geri dönüştürülebilir hibrit kağıtplastik ambalaj maddesi oluşturma kapasitesi; (e) atık depolama alanı hacimlerini azaltması; (f) tarımsal ekonomiyi iyileştirmesi ve (g) modifikasyonlar yoluyla fiziksel özelliklerinin değiştirilmesi (Marra ve ark., 2016). Bu avantajlarının aksine polilaktatların gaz bariyeri özelliği, nişasta bazlı malzemelerinkinden daha düşüktür (Bastioli, 2001). Bu kapsamda; polimer formülasyonlarına nano tabakalı katkı maddelerinin dahil edilmesi; matrikste yaratılan kıvrım, kristal çekirdeklenme ve zincir immobilizasyon etkileri nedeniyle bariyer özelliğini artırabilmektedir (Busolo ve ark., 2010). Bu amaçla, doğal montmorillonitlerin PLA bazlı kompozit filmlere eklenmesiyle materyallerde bariyer ve

43 | $\mathrm{P}$ a g e

www.iiste.org 
antimikrobiyal özelliklerin arttırıldığı saptanmıştır (Rhim ve ark., 2009). Bunlara ek olarak; PLA iyi görünüm, yüksek mekaniksel dayanım ve düşük toksisite gibi özelliklere de sahiptir. Ayrıca, PLA'dan gıdalara migrasyon çok sınırlı olup, geçebilecek küçük miktardaki bileşen ise laktik asit veya türevleri formundadır ve sivı sistemlerde hidrolize olabilirler (Jamshidian ve ark., 2010).

\section{Aktif Ambalajlama}

Literatürde aktif ambalajlama ile ilgili birçok tanım bulunmaktadır. Fakat genel olarak, aktif ambalajlama 'çeşitli bileşenlerin ambalaj sistemine dahil ederek, gıdaya ve gıdayı çevreleyen ortama istenen bileşenlerin salınmasına veya gıdayı çevreleyen ortamdaki istenmeyen bileșenlerin absorbe edilmesine olanak sağlayan' teknoloji olarak ifade edilmektedir (Yildirim ve ark., 2018). Aktif ambalajlama bileşenleri, gıda veya iç gaz atmosferi ile etkileşime girerek, yüksek kaliteli, taze ve güvenli ürünler sunulmasını sağlamaktadır. Bu teknoloji; besin kalitesini korurken, patojenik ve bozulmaya neden olan mikroorganizmaların büyümesini inhibe etmekte ve böylelikle raf ömrünü uzatmaktadır. Önemli aktif ambalajlama teknikleri içerisinde; oksijen tutucular, nem düzenleyiciler, etilen emiciler ve antimikrobiyal içeren filmler bulunmaktadır (Ozdemir ve Floros, 2004). Fakat herhangi bir aktif ambalajlama sistemini uygulamadan önce, gıdaların bozulma mekanizmasının anlaşılması gerekmektedir. Çünkü her ürünün farklı dış etmenlere (oksijen, ısı, ışık, nem vb.) gösterdiği tepki farklı olup, meydana gelen biyokimyasal veya mikrobiyal reaksiyonların hızı da bu faktörlere bağlı olarak değişmektedir (Bhardwaj ve ark., 2019).

Aktif bileşenler, birincil ambalajın dışına, birincil ambalajın farklı kısımlarının arasına veya birincil ambalajın içine yerleştirilebilmektedir. Bu son durumda, bileşenler yalnızca gıdayı çevreleyen atmosferle veya gıda yüzeyiyle temas halinde olabilmektedir (Dainelli ve ark., 2008). Eğer ambalaj içerisinde saket formunda kullanılıyorsa, üzerine yenilemez ibaresinin konularak, tüketicinin bu saketleri yanlışlıkla tüketmesinin önlenmesi gerekmektedir (Pereira de Abreu ve ark., 2012). Gelişmiş ülkelerde, aktif ambalajlama konsepti ticari olarak; etanol yayıcılar (unlu mamuller için), etilen emiciler (klimakterik meyveler için) ve karbondioksit yayıcılar/emiciler (kahve için) formunda kullanılmaktadır (Dainelli ve ark., 2008). Tahminlere göre aktif ve akıllı ambalajlama teknolojisi için küresel pazarın 2016 yılında sahip olduğu 13.75 milyar dolardan 2021 sonu itibarıly 23.38 milyar ABD dolarına büyümesi beklenmektedir (Bhardwaj ve ark., 2019).

\subsection{Aktif Ambalajlamada Biyobazlı Bileşenler}

Biyobazlı polimerlere spesifik biyoaktif bileşenlerin eklenmesi; onların fonksiyonel özelliklerini geliştirme, bakteri gelişimini inhibe etme ve aynı zamanda biyolojik olarak parçalanabilirliklerini koruma potansiyeli içermektedir. Biyoaktif maddelerin film matriksinden ambalaj üst boşluğuna veya gıda yüzeyine kontrollü bir hızda salınması sağlanarak gıdanın korunması mümkündür (Burgos ve ark., 2017). Aktif ambalajlama amaçlı kullanılan çeşitli biyobazlı bileşenler aşağıda verilmiştir.

\subsubsection{Antimikrobiyal Bileşenler}

Antimikrobiyal ambalajlama, aktif ambalajlamanın bir alt grubu olarak sınıflandırılmaktadır. Antimikrobiyal gida ambalajı, gida veya ambalaj malzemesinin kendisinde bulunabilen mikroorganizmaların büyümesini azaltma veya inhibe etmeyi sağlamaktadır (Appendini ve Hotchkiss, 2002).

Antimikrobiyal aktif ambalajlama amaçlı kullanılan bir bileșen de melanin olup, hayvan, bitki, bakteri ve mantarlar gibi çeşitli kaynaklardan izole edilebilmektedir. Melaninler genellikle siyah ve kahverengi pigmentler olup, yüksek moleküler ağırlıklı heterojen polimerler olarak da bilinmektedir. Melaninler polilaktik asit (PLA) gibi biyobazlı polimerlere eklendiğinde, Enterococcus faecalis, Pseudomonas aeruginosa ve Pseudomonas putida gibi mikroorganizmalara karşı etkili olup, aynı zamanda iyi bir antioksidant aktivite de sağlamaktadır (Lopusiewicz ve ark., 2018). Doğal ürünlerden elde edilen esansiyel yağlar da, genellikle mikrobiyal gelişimi engelleyen aktif bileşenler içermektedir. Kekik yağından ekstrakte edilen bir tür aktif madde olan timol, içerdiği fenolik bileşikler nedeniyle antioksidan ve antimikrobiyal özelliklerde önemli rol oynadığı için gıda, ilaç ve biyomedikal alanlarda yaygın olarak kullanılmaktadır. Biyobazlı PLA'ya eklenen timolün, gram pozitif bakterilerden Staphylococcus aureus' a karşı etkili olduğu ve bu nedenle et, meyve ve sebze gibi ürünlerde potansiyeli olduğu bildirilmiştir (Mohamad ve ark., 2020).

\subsubsection{Antioksidan Bileşenler}

Gıda ürünleri genellikle oksijene duyarlıdır, bu da renk modifikasyonları, istenmeyen tatların gelişimi

44 I P a g e

www.iiste.org 
ve ayrıca besin özelliklerinin bozulması gibi organoleptik özelliklerde istenmeyen değişikliklere neden olur ve mikrobiyal büyümeyi destekler. Bu sebeplerden ötürü, gıda paketlerinin tepe boşluğundaki oksijen içeriğini en aza indirmeyi amaçlayan stratejilere büyük önem verilmektedir (Drago ve ark., 2020). Oksijen içeriğinin azaltılması (vakum veya modifiye atmosfer paketleme ile) oksidasyon reaksiyonlarının kontrolü üzerinde bir etkiye sahip olsa da, bu sadece kısmi etkiyle sınırlıdır. Çünkü, gıdada çözünen oksijenin bu işlemlerle tamamen ortadan kaldırılması çok zordur. $\mathrm{Bu}$ nedenle ambalajdaki oksijen seviyelerinin kontrolünde, antioksidantların kullanılmasının önemi uzun süredir kabul edilmektedir (Sanches-Silva ve ark., 2014).

Kahve (Coffea arabica L.) ve kakao (Theobroma cocoa $L$.), zengin polifenol ve flavonoid kaynakları olup, antioksidan kaynağı olarak da bilinmektedir. Ayrıca kardiyovasküler, kanser, diyabet, obezite ve nörodejeneratif hastalıkların önlenmesinde potansiyel yararları olup, tüketiciler tarafindan benimsenen gıdalardır. Palm yağının ambalajlanmasında kullanılan ve kahve-kakao-nişasta üçlüsünden oluşan polimerin, antioksidan etki gösterdiği fakat mekaniksel özellikleri negatif yönde etkilediği tespit edilmiştir (Veiga-Santos ve ark., 2018). Zeytin (Olea europeae) ve zeytinyağı, mükemmel antioksidan özelliklere sahip çok sayıda polifenol içeren diğer bir üründür. Özellikle, hidroksitirosol (HT) ve 3,4dihidroksifenilglikol (DHPG), önemli antioksidan özelliklere sahip olup, zeytin meyvesi ve zeytinyağında bol miktarda bulunan iki ayrı fenoldür. Pektin-jelatin bazlı ambalaj materyaline bu iki bileşikle beraber eklenen balmumunun, antioksidan etki gösterdiği ve bu nedenle et ve ürünlerinde oksidasyonu engelleyebileceği rapor edilmiştir (Bermúdez-Oria ve ark., 2019). Diğer bir antioksidan olan vanilin (4-hidroksi-3-metoksibenzaldehit), vanilya çekirdeklerinin ana bileşenidir ve dondurma, çikolata ve şekerleme ürünleri gibi birçok gıdada kullanılan temel bir tatlandırıcı bileşiğidir. Vanilinin, çoklu doymamış yağ asitleri içeren gıdalarda bir antioksidan görevi gösterdiği de bildirilmiştir. Ayrıca, son çalışmalar vanilinin meyve püreleri ve meyve bazlı sistemlerde test edildiğinde maya ve küfleri önlemede etkili olabileceğini göstermiştir. Bazı mayaların vanilini kendi alkol ve asit türevlerine dönüştürebildiği bilinmektedir (Fitzgerald ve ark., 2003). Vanilin alkol bu türevlerden bir tanesi olup, PLA'ya aktif bileşen olarak eklendiğinde antioksidan etki göstererek, salamlarda lipid oksidasyonu engellediği tespit edilmiştir (Ortenzi ve ark., 2020). Biyobazlı aktif ambalajlama uygulamaları için potansiyel bir $\mathrm{O}_{2}$ tutucu da gallik asit (GA) olup, alkali koşullar altında büyük miktarda $\mathrm{O}_{2}$ emmektedir. Fakat ambalaj malzemesinde alkali koşullar sağlamak için, GA'nın bir baz ile birleştirilmesi gerekmektedir. $\mathrm{GA}$ ve $\mathrm{O}_{2}$ arasındaki reaksiyon sırasında, hangi bazın kullanıldığına bağlı olarak beyazdan (saf GA) koyu kahverengiye, koyu yeşile veya siyaha doğru bir renk değişimi gözlemlenebilmektedir. Bu nedenle, $\mathrm{GA}$ aynı zamanda bir $\mathrm{O}_{2}$ göstergesi olarak da kullanılabilmektedir. Biyobazlı çok katmanlı ambalaj filmine eklenen gallik asidin, nem içeriğinin artmasıyla oksijen tutucu özelliğinde de iyileşme tespit edilmiş̧ir (Pant ve ark., 2017).

\subsubsection{Nem Düzenleyiciler}

Gıdaların bozulmasının bir nedeni de gıdalardaki nem / su varlı̆̆ıdır. Balık, kümes hayvanları, et ve taze ürünler gibi su aktivitesi yüksek gıdaların ambalajlarının içindeki nem, bakteri ve küf oluşumunu hızlandırmakta ve bu da besin ve kalite kayıplarına yol açmaktadır. Bu nedenle ambalajın içindeki yüksek nemin kontrolü; mikrobiyal büyümenin engellenmesi ve gıdanın duyusal özelliklerinin iyileştirilmesi için çok önemlidir (Gaikwad ve ark., 2019).

Kağıt/karton malzemeler gıdaların ambalajlanmasında kullanılan diğer bir ambalaj materyali olup, biyobozunur olması nedeniyle yaygın olarak kullanılmaktadır. Ayrıca üzerine çeşitli bileşenlerle yapılan kaplamalar sayesinde gıdaların raf ömrünün artırılmasında da kullanılabilmektedir. Karton ambalajın su bariyeri özelliğini geliştirmek amacıyla yapılan PLA hidrofobik kaplamanın, ambalajın su buharı geçirgenliğini düşürdügü tespit edilmiştir (Taboada-Rodríguez ve ark., 2013).

\subsubsection{Etilen Tutucular}

Meyvelerden salınan etilen, meyvenin büyüme, olgunlaşma ve çimlenme süreçleriyle ilişkilidir. Etilenin bu süreçlerde oynadığı roller genellikle meyvelerin doğası, olgunluk durumu ve meyvelerin etilene maruz kalma derecesi tarafından yönetilmektedir. Etilen, meyve olgunlaşmasını hızlandırmanın yanı sıra, genellikle aşırı olgunlaşmaya ve hatta çürümeye neden olarak raf ömrünü kısaltmakta ve kayıplara neden olmaktadır. Bu nedenle, meyvelerin olgunlaşmasını yavaşlatmak için etilen sentez inhibitörleri veya tutucular kullanmak, hasat sonrası gıda kalitesinin korumasında kritiktir (Wei ve ark., 2021).

Aktif ambalajlama konseptinde, çeltik samanı pulpu, glukomannan ve etilen tutucu olarak hindistan cevizinden elde edilen aktif karbondan oluşan kağıt ambalajda, aktif karbon miktarının artırılmasıyla

45 | P a g e

www.iiste.org 
etilen adsorpsiyon kapasitesinin arttığı bulunmuştur. $\mathrm{Bu}$ nedenle bu ambalaj materyalinin gıda ambalajlamada olumlu sonuçlar verebileceği vurgulanmıştır (Sothornvit ve Sampoompuang, 2012).

\section{Sonuc}

Biyobazlı ambalajların gıda teknolojisindeki uygulamaları, biyobozunur olmalarından dolayı petrokimya bazlı plastiklerle karşılaştırıldığında çevre dostu bir alternatif sağlamaktadır. Buna karşılık, biyobazlı polimerlerin sahip olduğu zayıf mekaniksel ve bariyer özelliklerin çeşitli bileşenlerle geliştirilmesi gerekmektedir. Bu kapsamda biyobazlı polimerlere eklenecek olan aktif bileşenler, hem ambalajların özelliklerini geliştirecek, hem de bu polimerlerle ambalajlanan gıdaların kalitesinin korunmasına ve raf ömrünün uzatılmasına yardımcı olabilecektir.

\section{Referanslar}

Abdul Khalil, H.P.S., Davoudpour, Y., Islam, M.N., Mustapha, A., Sudesh, K., Dungani, R., \& Jawaid, M. (2014). Production and modification of nanofibrillated cellulose using various mechanical processes: A review. Carbohydrate Polymers, 99, 649-665.

Aday, M.S., \& Yener, U. (2014). Understanding the buying behaviour of young consumers regarding packaging attributes and labels. International Journal of Consumer Studies, 38(4), 385-393.

Appendini, P., \& Hotchkiss, J.H. (2002). Review of antimicrobial food packaging. Innovative Food Science \& Emerging Technologies, 3(2), 113-126.

Avella, M., De Vlieger, J.J., Errico, M.E., Fischer, S., Vacca, P., \& Volpe, M.G. (2005). Biodegradable starch/clay nanocomposite films for food packaging applications. Food Chemistry, 93(3), 467-474.

Barska, A., \& WyrWa, J. (2017). Innovations in the food packaging market-intelligent packaging-a review. Czech Journal of Food Sciences, 35(1), 1-6.

Bastioli, C. (2001). Global status of the production of biobased packaging materials. Starch-Stärke, 53(8), 351-355.

Bermúdez-Oria, A., Rodríguez-Gutiérrez, G., Rubio-Senent, F., Fernández-Prior, Á., \& FernándezBolaños, J. (2019). Effect of edible pectin-fish gelatin films containing the olive antioxidants hydroxytyrosol and 3, 4-dihydroxyphenylglycol on beef meat during refrigerated storage. Meat Science, 148, 213-218.

Bhardwaj, A., Alam, T., \& Talwar, N. (2019). Recent advances in active packaging of agri-food products: a review. Journal of Postharvest Technology, 7(1), 33-62.

Bhat, R., Abdullah, N., Din, R.H., \& Tay, G.S. (2013). Producing novel sago starch based food packaging films by incorporating lignin isolated from oil palm black liquor waste. Journal of Food Engineering, 119(4), 707-713.

Biji, K.B., Ravishankar, C.N., Mohan, C.O., \& Gopal, T.K.S. (2015). Smart packaging systems for food applications: a review. Journal of Food Science and Technology, 52(10), 6125-6135.

Burgos, N., Armentano, I., Fortunati, E., Dominici, F., Luzi, F., Fiori, S., Cristofaro, F., Visai, L., Jiménez, A., \& Kenny, J.M. (2017). Functional properties of plasticized bio-based poly (lactic acid) poly (hydroxybutyrate)(PLA_PHB) films for active food packaging. Food and Bioprocess Technology, 10(4), 770-780. 
Busolo, M.A., Fernandez, P., Ocio, M.J., \& Lagaron, J.M. (2010). Novel silver-based nanoclay as an antimicrobial in polylactic acid food packaging coatings. Food Additives \& Contaminants: Part A, 27(11), 1617-1626.

Cazon, P., \& Vazquez, M. (2020). Mechanical and barrier properties of chitosan combined with other components as food packaging film. Environmental Chemistry Letters, 18(2), 257-267.

Cazón, P., \& Vázquez, M. (2021). Bacterial cellulose as a biodegradable food packaging material: A review. Food Hydrocolloids, 113, 106530.

Chung, Y.L., Ansari, S., Estevez, L., Hayrapetyan, S., Giannelis, E.P., \& Lai, H.-M. (2010). Preparation and properties of biodegradable starch-clay nanocomposites. Carbohydrate Polymers, 79(2), 391-396.

Cutter, C.N. (2006). Opportunities for bio-based packaging technologies to improve the quality and safety of fresh and further processed muscle foods. Meat Science, 74(1), 131-142.

Dainelli, D., Gontard, N., Spyropoulos, D., Zondervan-van den Beuken, E., \& Tobback, P. (2008). Active and intelligent food packaging: legal aspects and safety concerns. Trends in Food Science \& Technology, 19, 103-112.

Datta, R., Tsai, S.P., Bonsignore, P., Moon, S.H., \& Frank, J.R. (1995). Technological and economic potential of poly (lactic acid) and lactic acid derivatives. FEMS microbiology reviews, 16(2-3), $221-231$

Drago, E., Campardelli, R., Pettinato, M., \& Perego, P. (2020). Innovations in smart packaging concepts for food: An extensive review. Foods, 9(11), 1628

Fitzgerald, D.J., Stratford, M., \& Narbad, A. (2003). Analysis of the inhibition of food spoilage yeasts by vanillin. International Journal of Food Microbiology, 86(1-2), 113-122.

Gaikwad, K.K., Singh, S., \& Ajji, A. (2019). Moisture absorbers for food packaging applications. Environmental Chemistry Letters, 17(2), 609-628.

Gan, I., \& Chow, W.S. (2018). Antimicrobial poly(lactic acid)/cellulose bionanocomposite for food packaging application: A review. Food Packaging and Shelf Life, 17, 150-161.

Goy, R.C., Britto, D.D., \& Assis, O.B.G. (2009). A review of the antimicrobial activity of chitosan. Polimeros-Ciencia E Tecnologia, 19(3), 241-247.

Hamed, I., Özogul, F., \& Regenstein, J.M. (2016). Industrial applications of crustacean by-products (chitin, chitosan, and chitooligosaccharides): A review. Trends in Food Science \& Technology, 48, 40-50.

Heydari, A., Alemzadeh, I., \& Vossoughi, M. (2013). Functional properties of biodegradable corn starch nanocomposites for food packaging applications. Materials \& Design, 50, 954-961.

Jabeen, N., Majid, I., \& Nayik, G.A. (2015). Bioplastics and food packaging: A review. Cogent Food \& Agriculture, 1(1), 1117749.

Jamshidian, M., Tehrany, E.A., Imran, M., Jacquot, M., \& Desobry, S. (2010). Poly-lactic acid: production, applications, nanocomposites, and release studies. Comprehensive Reviews in Food Science and Food Safety, 9(5), 552-571.

Kaewtatip, K., \& Thongmee, J. (2013). The effects of cross-linked starch on the properties of thermoplastic starch. Materials \& Design, 45, 586-589.

47 | $P$ a g e

www.iiste.org 
Łopusiewicz, Ł., Jędra, F., \& Mizielińska, M. (2018). New poly (lactic acid) active packaging composite films incorporated with fungal melanin. Polymers, 10(4), 386.

Marra, A., Silvestre, C., Duraccio, D., \& Cimmino, S. (2016). Polylactic acid/zinc oxide biocomposite films for food packaging application. International Journal of Biological Macromolecules, 88, 254-262.

Mitelut, A.C., Tănase, E.E., Popa, V.I., \& Popa, M.E. (2015). Sustainable alternative for food packaging: Chitosan biopolymer-A Review. AgroLife Scientific Journal, 4(2), 52-61.

Mohamad, N., Mazlan, M.M., Tawakkal, I.S.M.A., Talib, R.A., Kian, L.K., Fouad, H., \& Jawaid, M. (2020). Development of active agents filled polylactic acid films for food packaging application. International Journal of Biological Macromolecules, 163, 1451-1457.

Muller, J., González-Martínez, C., \& Chiralt, A. (2017). Combination of poly (lactic) acid and starch for biodegradable food packaging. Materials, 10(8), 952.

Nechyporchuk, O., Belgacem, M.N., \& Bras, J. (2016). Production of cellulose nanofibrils: A review of recent advances. Industrial Crops and Products, 93, 2-25.

Niranjana Prabhu, T., \& Prashantha, K. (2018). A review on present status and future challenges of starch based polymer films and their composites in food packaging applications. Polymer Composites, 39(7), 2499-2522.

Noorbakhsh-Soltani, S.M., Zerafat, M.M., \& Sabbaghi, S. (2018). A comparative study of gelatin and starch-based nano-composite films modified by nano-cellulose and chitosan for food packaging applications. Carbohydrate Polymers, 189, 48-55.

Ortenzi, M.A., Gazzotti, S., Marcos, B., Antenucci, S., Camazzola, S., Piergiovanni, L., Farina, H., Di Silvestro, G., \& Verotta, L. (2020). Synthesis of polylactic acid initiated through biobased antioxidants: Towards intrinsically active food packaging. Polymers, 12(5), 1183.

Ozdemir, M., \& Floros, J.D. (2004). Active food packaging technologies. Critical Reviews in Food Science and Nutrition, 44(3), 185-193.

Pant, A.F., Sängerlaub, S., \& Müller, K. (2017). Gallic acid as an oxygen scavenger in bio-based multilayer packaging films. Materials, 10(5), 489.

Paunonen, S. (2013). Strength and barrier enhancements of cellophane and cellulose derivative films: a review. BioResources, 8(2), 3098-3121.

Peelman, N., Ragaert, P., De Meulenaer, B., Adons, D., Peeters, R., Cardon, L., Van Impe, F., \& Devlieghere, F. (2013). Application of bioplastics for food packaging. Trends in Food Science \& Technology, 32(2), 128-141.

Pereira de Abreu, D.A., Cruz, J.M., \& Paseiro Losada, P. (2012). Active and intelligent packaging for the food industry. Food Reviews International, 28(2), 146-187.

Petersen, K., Nielsen, P.V., Bertelsen, G., Lawther, M., Olsen, M.B., Nilsson, N.H., \& Mortensen, G. (1999). Potential of biobased materials for food packaging. Trends in Food Science \& Technology, 10(2), 52-68.

Piñeros-Hernandez, D., Medina-Jaramillo, C., López-Córdoba, A., \& Goyanes, S. (2017). Edible cassava starch films carrying rosemary antioxidant extracts for potential use as active food packaging. Food Hydrocolloids, 63, 488-495. 
Priyadarshi, R., \& Rhim, J.W. (2020). Chitosan-based biodegradable functional films for food packaging applications. Innovative Food Science \& Emerging Technologies, 62, 102346.

Rhim, J.W., Hong, S.I., \& Ha, C.S. (2009). Tensile, water vapor barrier and antimicrobial properties of PLA/nanoclay composite films. LWT-Food Science and Technology, 42(2), 612-617.

Sanches-Silva, A., Costa, D., Albuquerque, T.G., Buonocore, G.G., Ramos, F., Castilho, M.C., Machado, A.V., \& Costa, H.S. (2014). Trends in the use of natural antioxidants in active food packaging: a review. Food Additives \& Contaminants: Part A, 31(3), 374-395.

Siracusa, V., Blanco, I., Romani, S., Tylewicz, U., Rocculi, P., \& Rosa, M.D. (2012). Poly(lactic acid)-modified films for food packaging application: Physical, mechanical, and barrier behavior. Journal of Applied Polymer Science, 125(2), 390-401.

Sothornvit, R., \& Sampoompuang, C. (2012). Rice straw paper incorporated with activated carbon as an ethylene scavenger in a paper-making process. International Journal of Food Science \& Technology, 47(3), 511-517.

Srinivasa, P.C., \& Tharanathan, R.N. (2007). Chitin/chitosan-Safe, ecofriendly packaging materials with multiple potential uses. Food Reviews International, 23(1), 53-72.

Taboada-Rodríguez, A., García-García, I., Cava-Roda, R., Lopez-Gomez, A., \& Marín-Iniesta, F. (2013). Hydrophobic properties of cardboard coated with polylactic acid and ethylene scavengers. Journal of Coatings Technology and Research, 10(5), 749-755.

Tawakkal, I.S.M.A., Cran, M.J., Miltz, J., \& Bigger, S.W. (2014). A review of poly(lactic acid)based materials for antimicrobial packaging. Journal of Food Science, 79(8), 1477-1490.

van den Broek, L.A.M., Knoop, R.J.I., Kappen, F.H.J., \& Boeriu, C.G. (2015). Chitosan films and blends for packaging material. Carbohydrate Polymers, 116, 237-242.

Veiga-Santos, P., Silva, L.T., de Souza, C.O., da Silva, J.R., Albuquerque, E.C.C., \& Druzian, J.I. (2018). Coffee-cocoa additives for bio-based antioxidant packaging. Food Packaging and Shelf Life, 18, 37-41.

Wang, H., Qian, J., \& Ding, F. (2018). Emerging chitosan-based films for food packaging applications. Journal of Agricultural and Food Chemistry, 66(2), 395-413.

Weber, C.J., Haugaard, V., Festersen, R., \& Bertelsen, G. (2002). Production and applications of biobased packaging materials for the food industry. Food Additives \& Contaminants, 19(S1), 172-177.

Wei, H., Seidi, F., Zhang, T., Jin, Y., \& Xiao, H. (2021). Ethylene scavengers for the preservation of fruits and vegetables: A review. Food Chemistry, 337, 127750.

Yildirim, S., Röcker, B., Pettersen, M.K., Nilsen-Nygaard, J., Ayhan, Z., Rutkaite, R., Radusin, T., Suminska, P., Marcos, B., \& Coma, V. (2018). Active packaging applications for food. Comprehensive Reviews in Food Science and Food Safety, 17(1), 165-199. 